\title{
Predominant Role of Gluconeogenesis in the Hepatic Glycogen Repletion of Diabetic Rats
}

\author{
Andrea Giaccari and Luciano Rossetti \\ Diabetes Division, Department of Medicine, University of Texas Health Science Center, San Antonio, Texas 78284
}

\begin{abstract}
Liver glycogen formation can occur via the direct (glucose $\rightarrow$ glucose-6-phosphate $\rightarrow$ glycogen) or indirect (glucose $\rightarrow \mathbf{C}_{3}$ compounds $\rightarrow$ glucose-6-phosphate $\rightarrow$ glycogen) pathways. In the present study we have examined the effect of hyperglycemia on the pathways of hepatic glycogenesis, estimated from liver uridine diphosphoglucose (UDPglucose) specific activities, and on peripheral (muscle) glucose metabolism in awake, unstressed control and $\mathbf{9 0 \%}$ pancreatectomized, diabetic rats. Under identical conditions of hyperinsulinemia $(\sim 550 \mu \mathrm{U} /$ $\mathrm{ml})$, 2-h euglycemic (6 mM) and hyperglycemic (+5.5 $\mathrm{mM}$ and $+11 \mathrm{mM}$ ) clamp studies were performed in combination with $\left.\left[3-{ }^{3} \mathrm{H}, \mathrm{U}-{ }^{14} \mathrm{C}\right] g l u c o s e,\left[6-{ }^{3} \mathrm{H}, \mathrm{U}-{ }^{14} \mathrm{C}\right] g\right]$ cose, or $\left.\left[3-{ }^{3} \mathrm{H}\right] g\right]$ lucose and $\left[\mathrm{U}-{ }^{14} \mathrm{C}\right]$ lactate infusions under postabsorptive conditions. Total body glucose uptake and muscle glycogen synthesis were decreased in diabetic vs. control rats during all the clamp studies, whereas glycolytic rates were similar. By contrast, hyperglycemia determined similar rates of liver glycogen synthesis in both groups. Nevertheless, in diabetic rats, the contribution of the direct pathway to hepatic glycogen repletion was severely decreased, whereas the indirect pathway was markedly increased. After hyperglycemia, hepatic glucose-6-phosphate concentrations were increased in both groups, whereas UDPglucose concentrations were reduced only in the control group. These results indicate that in the diabetic state, under hyperinsulinemic conditions, hyperglycemia normally stimulates liver glycogen synthesis through a marked increase in the indirect pathway, which in turn may compensate for the reduction in the direct pathway. The increase in the hepatic concentrations of both glucose-6-phosphate and UDPglucose suggests the presence, in this diabetic rat model, of a compensatory "push" mechanism for liver glycogen repletion. (J. Clin. Invest. 1992. 89:3645.) Key words: diabetes • gluconeogenesis • glycogen • hyperglycemia $\bullet$ liver
\end{abstract}

\section{Introduction}

When a glucose load is administered in the fasting or postabsorptive state, the liver switches from net glucose production to net glucose uptake (1-6), and liver glycogen stores are repleted. However, it is now well established, that, after glucose administration, in both animals (7-20) and humans (21-24), a significant portion of liver glycogen is not repleted through the classi-

Address reprint requests to Dr. Rossetti at his current address: Division of Endocrinology, Department of Medicine, Albert Einstein College of Medicine, 1300 Morris Park Avenue, Bronx, NY 10461.

Received for publication 3 December 1990 and in revised form 22 August 1991.

J. Clin. Invest.

(C) The American Society for Clinical Investigation, Inc.

$0021-9738 / 92 / 01 / 0036 / 10 \quad \$ 2.00$

Volume 89, January 1992, 36-45 cal direct pathway (i.e., glucose is taken up by the liver and directly converted into glucose-6-phosphate $\rightarrow$ glucose-1-phosphate $\rightarrow$ uridine diphosphoglucose (UDPglucose) ${ }^{1} \rightarrow$ glycogen), but through an indirect pathway, in which the glucose carbon skeleton is first cleaved to $\mathrm{C}_{3}$ compounds, reconstituted through the gluconeogenic pathway to glucose-6-phosphate, and finally converted into glucose-1-phosphate $\rightarrow$ UDPglucose $\rightarrow$ glycogen. Several studies suggest that in non-insulindependent diabetes mellitus (NIDDM), the contribution of gluconeogenesis to hepatic glucose output is increased, and plays a major role in the augmented plasma glucose concentration and hepatic glucose production during the postabsorptive state (25-27).

Recent observations also suggest that the inhibition of lactate/alanine gluconeogenesis by insulin may be mediated via diversion of three-carbon compounds toward other pathways, namely oxidation and glycogen formation (28), rather than via an insulin-induced reduction of the influx of these substrates into the liver. Thus, insulin may inhibit the gluconeogenic flux to plasma glucose at the level of glucose-6-phosphate, where it directs the newly formed glucose to glycogen instead to plasma. Consistent with this hypothesis, if gluconeogenesis is increased in the diabetic state, the contribution of the indirect (gluconeogenic) pathway to the liver glycogen repletion would also be expected to be altered. In fact, since physiological insulin concentrations have been shown to decrease the hepatic mRNA level of phosphoenolpyruvate-carboxy-kinase (29), independently of glucagon and cyclic AMP, it may be suggested that prolonged insulin deficiency and/or hepatic insulin resistance may determine an increase in overall gluconeogenic flux, involving both hepatic glucose output and glycogen formation. However, an alternative hypothesis may predict a diversion of gluconeogenic flux away from glycogen synthesis and toward glucose-6-phosphatase, at the level of the glucose-6-phosphate pool, thus without any alteration in the contribution of this pathway to liver glycogen repletion.

To delineate the impact of the diabetic state on the direct versus indirect pathways of liver glycogen repletion, we studied control and diabetic conscious rats under identical conditions of hyperinsulinemia and measured the specific activity of hepatic UDPglucose, the direct precursor of glycogen, at the end of the insulin clamp study. This allowed us to examine the pathways of liver glycogen repletion independently from the basal glycogen concentration. Because the circulating plasma glucose concentration is believed to be the major determinant of the pathways by which liver glycogen is repleted in normal rats $(14,17)$, we also examined the relationship between the plasma glucose concentration and hepatic glycogenesis by the direct vs. indirect pathway in conscious unrestrained control and diabetic ( $90 \%$ pancreatectomized) rats.

1. Abbreviations used in this paper: PEP, phosphoenolpyruvate; UDPglucose, uridine diphosphoglucose. 


\section{Methods}

Animals. Two groups of male Sprague-Dawley rats (Charles River Breeding Laboratories, Inc., Wilmington, MA) were studied: group I, sham-operated controls $(n=26)$; group II, partially pancreatectomized rats $(n=18)$. At 3-4 wk of age, all rats $(80-100 \mathrm{~g})$ were anesthetized with phenobarbital $(50 \mathrm{mg} / \mathrm{kg}$ body wt i.p.) and in group II $90 \%$ of the pancreas was removed according to the technique of Foglia (30), as modified by Bonner-Weir et al. (31). Group I underwent a sham pancreatectomy in which the pancreas was disengaged from the mesentery and gently rubbed between the fingers. Immediately after surgery (i.e., pancreatectomy or sham pancreatectomy) rats were housed in individual cages and subjected to a standard light ( 6 a.m. to 6 p.m.)-dark (6 p.m. to 6 a.m.) cycle. Based on prior experience, rats received the identical daily allotment of rat Chow (Ralston-Purina Co., St. Louis, MO) in an amount ( $0.1 \mathrm{~g} / \mathrm{g}$ body wt per $\mathrm{d}$ ) that sustained normal growth and was completely consumed by all of the animals. After surgery rats were weighed twice weekly and tail vein blood was collected for the determination of nonfasting plasma glucose and insulin concentrations at the same time ( 8 a.m.). The fasting plasma glucose and insulin concentrations also were determined weekly on tail vein blood.

Euglycemic clamp study. Whole-body glucose uptake was measured in awake, unstressed, chronically catheterized rats using the euglycemic clamp in combination with $\left[3-{ }^{3} \mathrm{H}, \mathrm{U}-{ }^{14} \mathrm{C}\right]$ glucose infusion as previously described (32-36). Briefly, $5 \mathrm{wk}$ after pancreatectomy or sham pancreatectomy, rats were anesthetized with an injection of phenobarbital $(50 \mathrm{mg} / \mathrm{kg}$ body wt i.p.) and indwelling catheters were inserted in the right internal jugular vein and in the left carotid artery. The venous catheter was extended to the level of the right atrium and the arterial catheter was advanced to the level of the aortic arch (3236). $1 \mathrm{wk}$ after catheter placement (6 wk after pancreatectomy or shamoperation) rats received an infusion of insulin at $18 \mathrm{mU} / \mathrm{kg} \cdot \min$ for 2 h. A variable infusion of $25 \%$ glucose solution was started at time 0 and adjusted to clamp the plasma glucose concentration at $\sim 6 \mathrm{mM}$ (euglycemic clamp), $\sim 11.5 \mathrm{mM}$ (+5.5 mM hyperglycemic clamp), or $\sim 17$ $\mathrm{mM}$ (+11 mM hyperglycemic clamp). A prime-continuous infusion of [3- ${ }^{3} \mathrm{H}, \mathrm{U}-{ }^{14} \mathrm{C}$ glucose (New England Nuclear, Boston, MA) was initiated at time 0 and continued throughout the study (32-36). Eight additional clamp studies were performed in control rats with infusion of [3- $\left.{ }^{3} \mathrm{H}\right]$ glucose and $\left[\mathrm{U}-{ }^{14} \mathrm{C}\right]$ lactate $(n=4,+11 \mathrm{mM})$ or $\left[6-{ }^{3} \mathrm{H}, \mathrm{U}-{ }^{14} \mathrm{C}\right]-$ glucose $(n=4,+5.5 \mathrm{mM})$. Five control and five diabetic $24-\mathrm{h}$ fasted rats received a saline infusion in combination with $\left[3-{ }^{3} \mathrm{H}\right]$ glucose and $\left[\mathrm{U}-{ }^{14} \mathrm{C}\right]$ lactate infusions, to allow us the measurement of basal hepatic glucose production and gluconeogenesis. Plasma samples for determination of $\left[{ }^{3} \mathrm{H},{ }^{14} \mathrm{C}\right]$ glucose, $\left[{ }^{14} \mathrm{C}\right]$ lactate, and tritiated water specific activities were obtained at 5-10-min intervals throughout the insulin clamp study. Plasma samples for determination of plasma insulin concentrations were obtained at time $-30,0,60,90$, and 120 min during the study. The total volume of blood withdrawn was $<3.0 \mathrm{ml}$ per study. To prevent volume depletion and anemia, insulin was diluted in a solution (1:1 vol/vol) of $\sim 4 \mathrm{ml}$ of fresh blood (obtained by heart puncture from a littermate of the test animal) and heparinized saline $(10 \mathrm{U} / \mathrm{ml})$. At the end of the 120-min study rats were injected with phenobarbital (60 $\mathrm{mg} / \mathrm{kg}$ body $\mathrm{wt}$ ), the abdomen was quickly opened, samples of portal vein blood and urines were collected, and the liver, abdominal rectus, and hindlimb muscles were freeze-clamped with aluminum tongs precooled in liquid nitrogen. All tissue samples were kept frozen at $-80^{\circ} \mathrm{C}$ for subsequent analysis. The study protocol was reviewed and approved by the Institutional Animal Care and Use Committee of the University of Texas Health Science Center at San Antonio.

Whole-body glucose uptake. Data for total body glucose uptake and suppression of hepatic glucose production represent the mean values during the last $30 \mathrm{~min}$. Residual hepatic glucose production was calculated by subtracting from the rate of total body glucose disposal during each insulin clamp the glucose infusion rate during the same time period. The urinary glucose losses during the $+11 \mathrm{mM}$ clamp were $2.2 \pm 0.2 \mu \mathrm{mol} / \mathrm{kg} \cdot \mathrm{min}$ in diabetic rats and $8.4 \pm 1.6 \mu \mathrm{mol} / \mathrm{kg} \cdot \min$ in control rats.
Muscle glycogen formation in vivo. Muscle glycogen synthesis was quantitated by two independent means: first, by determining the increment in cold glycogen concentration above fasting levels, and second, by measuring the incorporation of $\left[3-{ }^{3} \mathrm{H}\right]$ glucose counts into glycogen. Muscle glycogen concentrations were determined after digestion with amyloglucosidase as previously described (32-36). The intraassay and the interassay coefficients of variation were $<10 \%$ (at $14.0 \mathrm{mmol}$ of glucosyl units in glycogen per kilogram of tissue weight) when a muscle homogenate was assayed as multiple aliquots. The fasting glycogen concentration was measured in a separate group of 30 rats who were treated in a fashion identical (i.e., diet, housing, catheter insertion, 24-h fast, sacrifice, etc.) to that of the rats in groups I and II. Aliquots of the tissue homogenate $(200 \mu \mathrm{l})$ were employed to determine the amount of tritium label in glycogen. The recovery of free $\left[3-{ }^{3} \mathrm{H}\right]$ glucose, added to test the procedure, was $<1 \%$ of the free glucose radioactivity added to the homogenate in each assay. The glycogen synthetic rate was obtained by dividing the radioactivity of $\left[3-{ }^{3} \mathrm{H}\right]$ glucosyl units in glycogen (disintegrations per minute per kilogram of tissue weight) by the mean specific activity of $\left[3-{ }^{3} \mathrm{H}\right]$ glucose in plasma during the insulin clamp (disintegrations per minute per micromole). The rate of net glycogen synthesis is expressed as micromoles of glucose in glycogen per kilogram of body weight per minute.

Whole-body glycolytic flux in vivo. Because tritium on the C-3 position of glucose is lost to water during glycolysis, it can be assumed that, when $\left[3-{ }^{3} \mathrm{H}\right]$ glucose is infused, plasma tritium is present either in ${ }^{3} \mathrm{H}_{2} \mathrm{O}$ or $\left[3-{ }^{3} \mathrm{H}\right]$ glucose (37). Although tritium may also be released during fructose-6-phosphate cycling and/or pentose phosphate cycling, these pathways account for only a small percentage of the whole-body glucose turnover $(38-40)$. Thus, in the studies in which $\left[3-{ }^{3} \mathrm{H}\right]$ glucose was infused, aliquots of plasma were precipitated with $\mathrm{Ba}(\mathrm{OH})_{2}$ and $\mathrm{ZnSO}_{4}$ and centrifuged; plasma tritiated water specific activity was determined by liquid scintillation counting of the protein-free supernatant (Somogyi filtrate) before and after evaporation to dryness. Rates of whole-body glycolysis were estimated from the increment per unit time in tritiated water (disintegrations per minute per liter per minute) times the body water mass (liters) divided by the $\left[3-{ }^{3} \mathrm{H}\right]$ glucose specific activity (disintegrations per minute per micromole). Plasma water was assumed to be $93 \%$ of the total plasma volume and total body water mass was assumed to be $65 \%$ of the body mass (32). The calculation of glycolytic flux using the above approach assumes that the appearance of ${ }^{3} \mathrm{H}_{2} \mathrm{O}$ in plasma is representative of the appearance in the whole body and that the loss of ${ }^{3} \mathrm{H}_{2} \mathrm{O}$ during the $2 \mathrm{~h}$ of the experiment is negligible. Both of these assumptions were previously experimentally validated by performing saline infusions or clamp studies in normal $(n=10)$ and diabetic $(n=10)$ rats in combination with a constant infusion of ${ }^{3} \mathrm{H}_{2} \mathrm{O}$ (32).

Liver glycogen formation in vivo. Liver glycogen synthesis was quantitated by measuring the incorporation of $\left[{ }^{3} \mathrm{H}\right]$ glucose or $\left[{ }^{14} \mathrm{C}\right]-$ glucose counts into glycogen, and (only in sham-operated rats) by determining the increment in cold glycogen concentration above fasting levels. The techniques utilized for measuring glycogen concentration and radioactivity are identical to those for muscle glycogen. Coefficients of variation and recovery tests are also superimposable. The fasting glycogen concentration in the liver was measured in a separate group of 30 rats who were treated in an identical fashion. Hepatic glycogen concentration in 24-h fasted control rats was $25.5 \pm 0.2 \mathrm{mmol}$ of glucosyl units per kilogram of tissue weight, and this concentration was subtracted from those obtained in group I at the end of the clamp studies. Hepatic glycogen concentration in $24-\mathrm{h}$ fasted diabetic rats was $121.6 \pm 39.4 \mathrm{mmol}$ of glucosyl units per kilogram of tissue weight. The glycogen synthetic rate was obtained by dividing the $\left[{ }^{3} \mathrm{H}\right]$ glucosyl radioactivity or the $\left[{ }^{14} \mathrm{C}\right]$ glucosyl radioactivity in glycogen (disintegrations per minute per kilogram of tissue weight) by the liver $\left[{ }^{3} \mathrm{H}\right]$ UDPglucose or the $\left[{ }^{14} \mathrm{C}\right]$ UDPglucose specific activities (disintegrations per minute per micromole), respectively. To verify that hepatic glycogen synthesis occurs in a linear fashion in diabetic rats, liver glycogen synthesis was also measured in prolonged hyperglycemic clamp studies (up to $5 \mathrm{~h}$ ) and was shown to be similar to that measured at $2 \mathrm{~h}$. 
Contribution of direct and indirect pathways. When $\left[3-{ }^{3} \mathrm{H}\right]$ glucose was infused, the contribution of the direct pathway was calculated as the product of the liver glycogen synthetic rate (micromoles of glucose in glycogen per kilogram of body weight) and the factor obtained from the ratio of $\left[3-{ }^{3} \mathrm{H}\right]$ UDPglucose and $\left[3-{ }^{3} \mathrm{H}\right]$ glucose $(80 \%$ portal vein, $20 \%$ artery) specific activities (both in disintegrations per minute per micromole). It should be noted that, in this study, the plasma glucose specific activity was virtually identical in the peripheral and in the portal circulation. Therefore, the percent contribution of the portal vein blood flow to the hepatic blood flow, which was reported to be $72-80 \%$ by other investigators $(2-4,6)$, has a minimal impact on the calculation of the direct pathway of liver glycogen synthesis. In these studies, the contribution of the indirect pathway was estimated as the difference between the total liver glycogen synthesis and the calculated contribution of the direct pathway (both in micromoles of glucose in glycogen per kilogram of body weight). When $\left[6-{ }^{3} \mathrm{H}\right] g l u c o s e$ was infused, the maximal contribution of the direct pathway was calculated with the factor obtained from the ratio of $\left[6-{ }^{3} \mathrm{H}\right]$ UDPglucose and [6${ }^{3} \mathrm{H}$ ]glucose $(80 \%$ portal vein, $20 \%$ artery) specific activities (both in disintegrations per minute per micromole). In the experiments in which $\left[3-{ }^{3} \mathrm{H}\right]$ glucose and $\left[\mathrm{U}-{ }^{14} \mathrm{C}\right]$ lactate were infused, the gluconeogenic pathway was independently (from ${ }^{3} \mathrm{H}$ data) measured as the product of liver glycogen synthetic rate (micromoles of glucose in glycogen per kilogram of body weight) and the factor obtained from the ratio of $\left[{ }^{14} \mathrm{C}\right]$ UDPglucose and twice the $\left[{ }^{14} \mathrm{C}\right]$ phosphoenolpyruvate (PEP) specific activities (both in disintegrations per minute per micromole). The latter factor provides the percent contribution of the PEPgluconeogenesis to the hepatic glucose-6-phosphate pool and thus to both total glucose output and glycogen synthesis. Total glucose output $(\mathrm{TGO})=$ hepatic glucose production (HGP) + glucose cycling (GC). The ratio of $\left[3-{ }^{3} \mathrm{H}\right]$ UDPglucose and $\left[3-{ }^{3} \mathrm{H}\right]$ glucose specific activities measures the percentage of the hepatic glucose-6-phosphate pool which is derived from plasma glucose. Thus, this ratio also measures the percent contribution of glucose cycling to TGO. Therefore, TGO can be calculated from the equation TGO $=\mathrm{HGP}+\mathrm{GC}$, by substituting GC with ([3$\left.{ }^{3} \mathrm{H}\right]$ UDPglucose $/\left[3-{ }^{3} \mathrm{H}\right]$ glucose specific activity) $\times$ TGO. The gluconeogenic flux to plasma glucose was calculated as $\left[{ }^{14} \mathrm{C}\right]$ UDPglucose specific activity $/ 2 \times\left[{ }^{14} \mathrm{C}\right] \mathrm{PEP}$ specific activity) $\times \mathrm{TGO}$.

Analytical procedures. Plasma glucose was measured by the glucose oxidase method (Glucose Analyzer II, Beckman Instruments, Inc., Palo Alto, CA) and plasma insulin by radioimmunoassay using rat and porcine insulin standards. Plasma $\left[{ }^{3} \mathrm{H}\right]$ glucose radioactivity was measured in duplicate on the supernatants of $\mathrm{Ba}(\mathrm{OH})_{2}$ and $\mathrm{ZnSO}_{4}$ precipitates (Somogyi procedure) of plasma samples after evaporation to dryness to eliminate tritiated water. Plasma $\left[{ }^{14} \mathrm{C}\right]$ glucose and $\left[{ }^{14} \mathrm{C}\right]$ lactate radioactivities were measured in duplicate after separation with ion-exchange resins, as previously described (1). Plasma lactate concentrations and liver glucose-6-phosphate concentrations were measured spectrophotometrically as described by Noll (41) and by Michal (42). UDPglucose and PEP concentrations and specific activities in the liver were obtained through two sequential chromatographic separations, by a modification of the method previously described (43). Briefly, the first is performed on a solid-phase, strong anion-exchange cartridge, with the use of phosphate buffers of increasing molarity. This first purification allows to partially separate the two compounds of interest from all nonpolar and the most of the polar intracellular substrates with optimal recoveries. The second step is a reversed phase, ion pairing HPLC isocratic method, on a $C_{18}$ column (Fig. 1). In order to provide evidence for the identity and purity of the chromatographic peaks, specific precolumn enzymatic conversions of UDPglucose and PEP were carried out. When these samples were injected into the HPLC system, no interfering peaks were eluted within the retention volumes of both PEP and UDPglucose (43).

\section{Results}

General characteristics of the animals. There were no differences in the mean body weights between control and diabetic

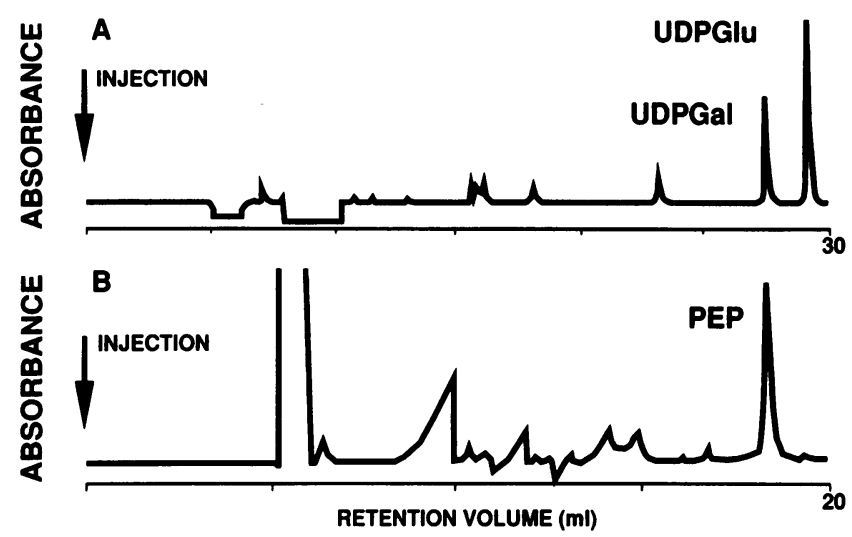

Figure 1. Typical HPLC chromatograms from liver homogenates for the separation of $(A)$ UDPglucose (UDPGlu) and $(B)$ PEP.

rats (Table I). Both the fasting $(P<0.05)$ and post-meal $(P$ $<0.01)$ plasma glucose concentrations during the 2 -wk period before the insulin clamp studies were significantly higher in the diabetic compared to the control group (Table I). The fasting plasma insulin concentrations were similar, whereas the postmeal plasma insulin concentration were significantly diminished in diabetic rats compared to controls $(P<0.01)$. Fasting free fatty acid and lactate concentrations were also similar in the two groups (Table I). Basal hepatic glucose production $(42.5 \pm 3.9$ vs. $35.5 \pm 2.1 \mu \mathrm{mol} / \mathrm{kg} \cdot \mathrm{min} ; P<0.05)$, glucose cycling $(8.1 \pm 0.8$ vs. $3.9 \pm 0.3 \mu \mathrm{mol} / \mathrm{kg} \cdot \min ; P<0.01)$, and PEP gluconeogenesis ( $39.4 \mathrm{vs.} 31.2 \mu \mathrm{mol} / \mathrm{kg} \cdot \mathrm{min} ; P<0.01)$ were increased in diabetic compared to control rats.

Insulin clamp studies. Steady-state plasma glucose and insulin concentrations during the insulin clamp studies were similar in the two groups (Table II). Steady-state conditions for both plasma glucose concentration and specific activity were reached within $\sim 30 \mathrm{~min}$ (Fig. 2). The coefficient of variation in plasma glucose level was $>5 \%$ in all studies. Hepatic glucose production was almost completely suppressed during all the clamp studies in both diabetic $(3.1 \pm 1.6,2.9 \pm 0.6$, and $2.8 \pm 1.3$ $\mu \mathrm{mol} / \mathrm{kg} \cdot \mathrm{min})$ and control rats $(3.0 \pm 1.8,2.2 \pm 0.9$, and $2.1 \pm 1.0$ $\mu \mathrm{mol} / \mathrm{kg} \cdot \min$ during the euglycemic, $+5.5 \mathrm{mM}$ and $+11 \mathrm{mM}$ clamp, respectively). During the euglycemic, hyperinsulinemic clamp study, the tissue glucose uptake (Fig. $3 \mathrm{~A}$ ) was significantly decreased in diabetic compared to control rats $(144.4 \pm 8.3$ vs. $188.9 \pm 8.3 \mu \mathrm{mol} / \mathrm{kg} \cdot \min , P<0.01)$. When hyperglycemia $(+5.5 \mathrm{mM}$ and $+11 \mathrm{mM})$ was added over hyperin-

Table I. General Characteristics of Control and Diabetic Rats

\begin{tabular}{lcc}
\hline \multicolumn{1}{c}{ Group } & Control & Diabetic \\
\hline$n$ & 26 & 18 \\
Body weight $(g)$ & $312 \pm 5$ & $302 \pm 9$ \\
Fasting plasma glucose $(m M)$ & $5.9 \pm 0.2$ & $7.1 \pm 0.5^{*}$ \\
Fasting plasma insulin $(\mu U / m l)$ & $31 \pm 4$ & $27 \pm 3$ \\
Fasting free fatty acids $(\mu M)$ & $483 \pm 31$ & $502 \pm 18$ \\
Fasting plasma lactate $(\mu M)$ & $541 \pm 42$ & $598 \pm 68$ \\
Nonfasting plasma glucose $(m M)$ & $7.4 \pm 0.3$ & $17.9 \pm 1.1^{*}$ \\
Nonfasting plasma insulin $(\mu U / m l)$ & $65 \pm 6$ & $37 \pm 4^{*}$
\end{tabular}

${ }^{*} P<0.01$ vs. controls 
Table II. Steady-State Plasma Glucose and Insulin Concentrations

\begin{tabular}{lcc}
\hline \multicolumn{1}{c}{ Group } & Control & Diabetic \\
\hline Euglycemia $n$ & 6 & 6 \\
Glucose $(m M)$ & $6.2 \pm 0.3$ & $6.1 \pm 0.3$ \\
Insulin $(\mu U / m l)$ & $507 \pm 58$ & $492 \pm 49$ \\
Hyperglycemia $(+5.5 \mathrm{~mm}) n$ & 10 & 6 \\
Glucose $(m M)$ & $11.6 \pm 0.9$ & $11.6 \pm 1.0$ \\
Insulin $(\mu U / m l)$ & $541 \pm 32$ & $512 \pm 48$ \\
Hyperglycemia $(+11 \mathrm{mM}) n$ & 10 & 6 \\
Glucose $(m M)$ & $16.8 \pm 1.2$ & $17.1 \pm 1.1$ \\
Insulin $(\mu U / m l)$ & $566 \pm 51$ & $518 \pm 50$ \\
& & \\
\hline
\end{tabular}

sulinemia (Fig. $3 A$ ), the tissue glucose uptake in the diabetic rats, compared to control rats, was again significantly reduced (+5.5 mM-221.7 \pm 7.8 vs. $266.8 \pm 8.4 \mu \mathrm{mol} / \mathrm{kg} \cdot \mathrm{min} ;+11 \mathrm{mM}$ $-276.1 \pm 18.3$ vs. $352 \pm 14.0 \mu \mathrm{mol} / \mathrm{kg} \cdot \mathrm{min}$; diabetic vs. control rats, respectively). However, the increment in glucose uptake above the euglycemic condition, during the $+5.5 \mathrm{mM}$ or the $+11 \mathrm{mM}$ hyperglycemic clamp studies, were similar in diabetic vs. control rats $(+5.5 \mathrm{mM}-+77.3 \pm 7.8$ vs. $+77.9 \pm 8.4 \mu \mathrm{mol} /$ $\mathrm{kg} \cdot \min ;+11 \mathrm{mM}-+131.7 \pm 18.3$ vs. $+162.9 \pm 14.0 \mu \mathrm{mol} /$ $\mathrm{kg} \cdot \min ; P=\mathrm{NS})$.

Muscle glycogen synthesis. After the 24-h fast, the muscle glycogen concentration was similar in the control $(30.1 \pm 0.2$ $\mathrm{mmol} / \mathrm{kg}$ tissue $\mathrm{wt}$ ) compared to the diabetic $(29.4 \pm 0.2 \mathrm{mmol} /$ $\mathrm{kg}$ tissue wt) group. The determination of the rate of net muscle glycogen synthesis from the tracer incorporation in glycogen and from the increment in cold glycogen concentration, gave similar results (32-36). Fig. $3 B$ shows the results estimated from the increment in the cold glycogen concentration. During the euglycemic clamp, the increment in muscle glycogen con-

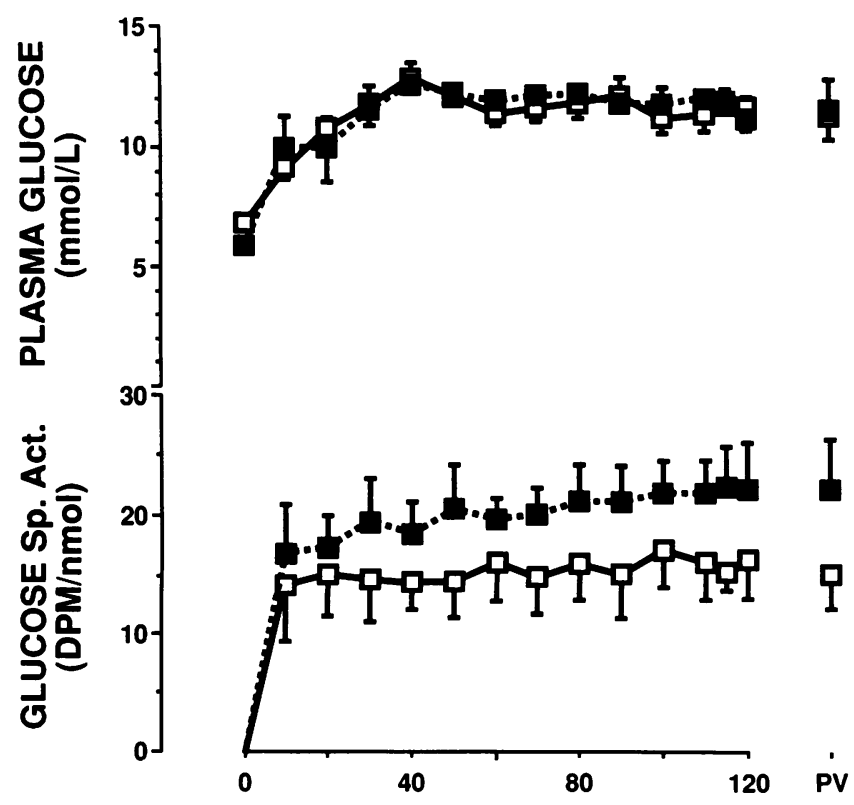

Figure 2. Plasma glucose concentrations (upper panel) and plasma $\left[{ }^{3} \mathrm{H}\right]$ glucose specific activity (lower panel) during the $+5.5 \mathrm{mM}$ hyperglycemic clamp in control ( $\square$ ) and $90 \%$ pancreatectomized diabetic rats (๘). PV, portal vein.

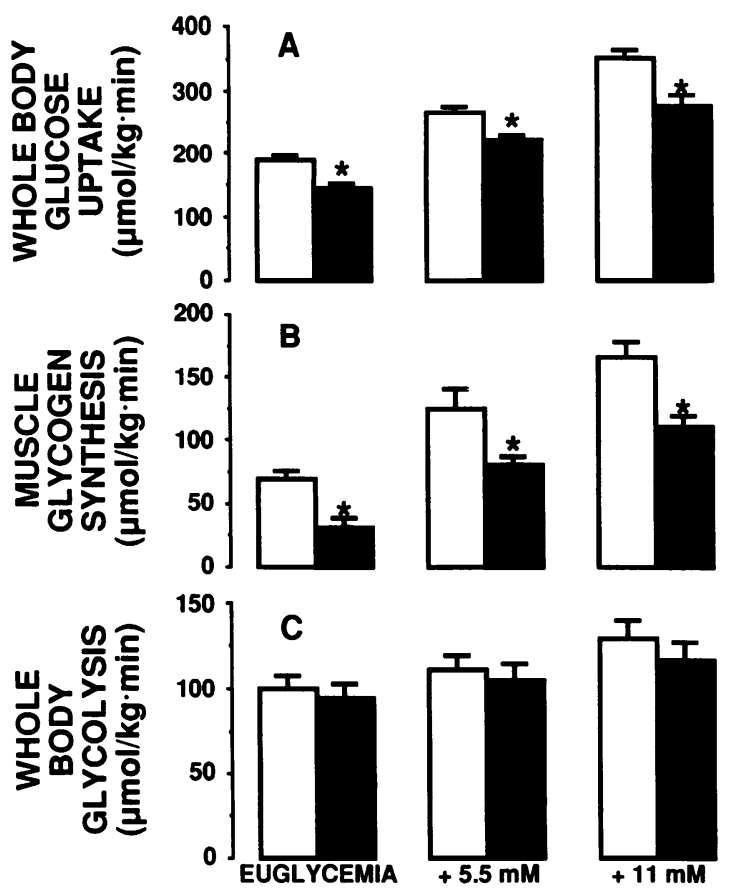

Figure 3. Effect of hyperglycemia on rates of $(A)$ whole-body glucose uptake, $(B)$ muscle glycogen synthesis, and $(C)$ whole-body glycolysis in sham-operated controls (open bars) and $90 \%$ pancreatectomized diabetic rats (solid bars). ${ }^{*} P<0.01$ or less vs. controls.

centration from fasting level in the diabetic rats was only $45 \%$ of that obtained in control rats $(9.2 \pm 0.7$ vs. $20.7 \pm 2.0 \mathrm{mmol} / \mathrm{kg}$ tissue wt, diabetic vs. control rats, respectively; $P<0.001)$. Net muscle glycogen synthesis was significantly stimulated during all the clamp studies in both groups (Fig. $3 \mathrm{~B}$ ), but was severely impaired in diabetic animals compared to controls (euglyce$\mathrm{mia}-30.6 \pm 2.2$ vs. $69.0 \pm 6.7 \mu \mathrm{mol} / \mathrm{kg} \cdot \mathrm{min} ;+5 \mathrm{mM}-$ $81.1 \pm 6.7$ vs. $125.1 \pm 16.0 \mu \mathrm{mol} / \mathrm{kg} \cdot \mathrm{min} ;+11 \mathrm{mM}-111.1 \pm 8.3$ vs. $166 \pm 12.0 \mu \mathrm{mol} / \mathrm{kg} \cdot \mathrm{min}$; diabetic vs. control rats, respectively; $P<0.01$ or less). In the hyperglycemic studies, the increase in muscle glycogen synthesis above that observed during the euglycemic clamp was similar in the two groups $(+5.5 \mathrm{mM}$ $-+15.1 \pm 2.0$ vs. $+16.8 \pm 4.8 \mathrm{mmol} / \mathrm{kg}$ tissue $\mathrm{wt} ;+11 \mathrm{mM}-$ $+24.1 \pm 2.5$ vs. $+29.1 \pm 3.6 \mathrm{mmoles} / \mathrm{kg}$ tissue wt; diabetic vs. control rats, respectively, $P=\mathrm{NS}$ ).

Whole-body glycolytic flux. During the hyperinsulinemic, euglycemic clamp studies, the whole-body glycolysis in control rats represented $52.9 \%$ of the whole-body glucose uptake, whereas it was $65.4 \%$ in the diabetic rats. However, the total

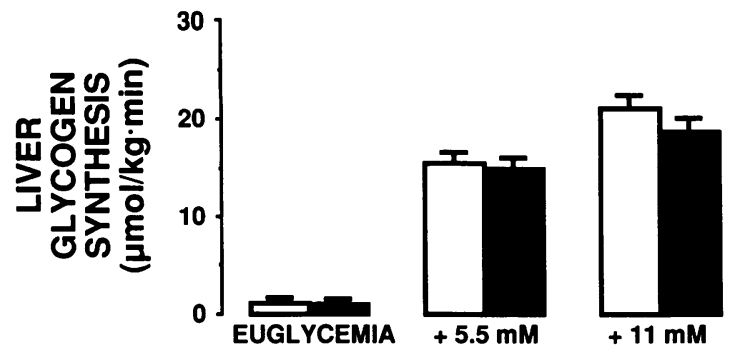

Figure 4. Effect of hyperglycemia on rates of liver glycogen synthesis in sham-operated controls (open bars) and $90 \%$ pancreatectomized diabetic rats (solid bars). 

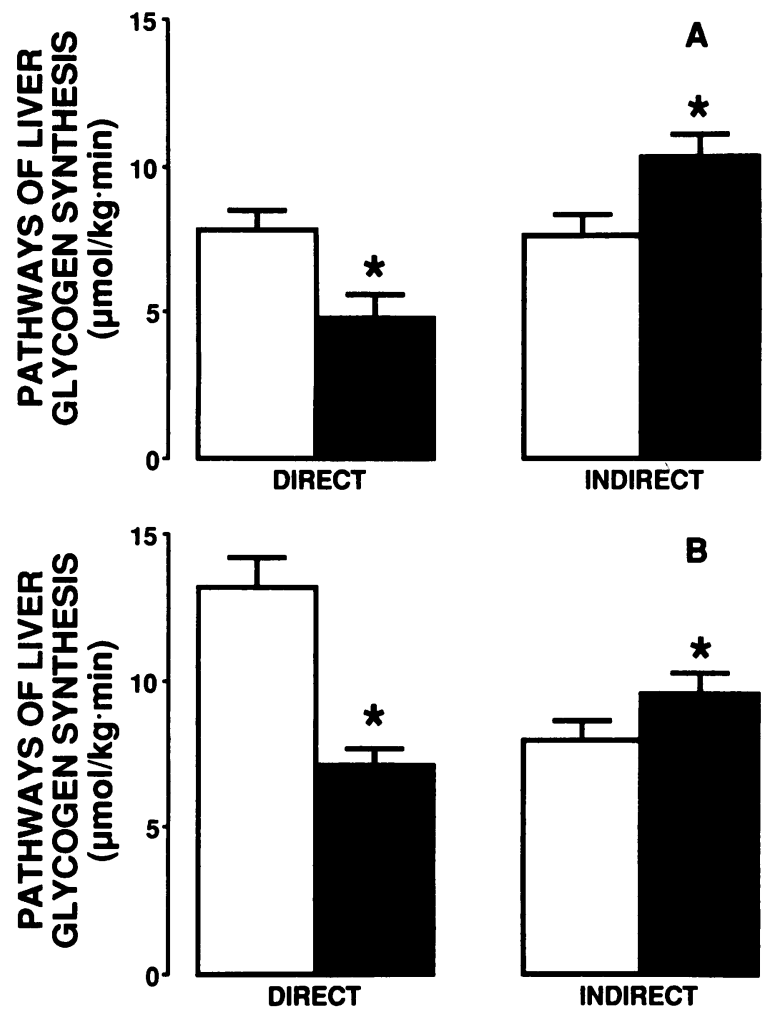

Figure 5. Contribution of the direct and the indirect pathways during the $(A)+5 \mathrm{mM}$ hyperglycemic clamp study and the $(B)+11 \mathrm{mM}$ hyperglycemic clamp study in sham-operated controls (open bars) and $90 \%$ pancreatectomized diabetic rats (solid bars). ${ }^{*} P<0.01$ or less vs. the same pathway in controls.

glycolytic flux (Fig. $3 \mathrm{C}$ ) was similar in the two groups $(94.4 \pm 8.3$ vs. $100 \pm 7.8 \mu \mathrm{mol} / \mathrm{kg} \cdot \mathrm{min}$; diabetic vs. control rats, respectively; $P=$ NS). When hyperglycemia was added over hyperinsulinemia, whole-body glycolysis was not significantly increased in either group. Tritiated water specific activity was also measured in liver, kidney, skeletal muscle, and urine at the end of the studies ( $n=4$ for each glycemic level). The highest specific activity was detected in skeletal muscle and the lowest in urine and kidney in all studies. This suggests that skeletal muscle is the major site of glycolysis under the present experimental conditions.

Liver glycogen synthesis. In control rats, the rates of liver glycogen synthesis derived from the tracers (ratio of the rate of accumulation of ${ }^{3} \mathrm{H}$ or ${ }^{14} \mathrm{C}$ radioactivity in liver glycogen over $\left[{ }^{3} \mathrm{H}\right]-$ or $\left[{ }^{14} \mathrm{C}\right]$ UDPglucose specific activities) and from the increment in the cold glycogen concentration gave similar results. On the contrary, the rate of liver glycogen synthesis cannot be accurately calculated from the increment in the cold glycogen concentration in diabetic rats, owing to the large variability in the basal hepatic glycogen concentration after the 24-h fast. Thus, the tracer-derived rates of liver glycogen synthesis are shown in Fig. 4. During the euglycemic, hyperinsulinemic clamp, the rates of liver glycogen synthesis were not statistically different from zero in both groups. However, during hyperglycemia, liver glycogen synthesis was significantly and equally stimulated in the two groups $(+5.5 \mathrm{mM}-442 \pm 31$ and $409 \pm 30 \mu \mathrm{mol} / \mathrm{kg}$ tissue $\mathrm{wt} \cdot \mathrm{min} ;+11 \mathrm{mM}-598 \pm 42$ and $514 \pm 45 \mu \mathrm{mol} / \mathrm{kg}$ tissue $\mathrm{wt} \cdot \mathrm{min}$; control and diabetic rats, respectively).

Pathways of liver glycogen synthesis. The contribution of the direct and indirect pathway to liver glycogen repletion in control rats was evaluated by three independent means (Fig. 5). In a series of studies, $\left[3-{ }^{3} \mathrm{H}\right]$ glucose and $\left[\mathrm{U}-{ }^{14} \mathrm{C}\right]$ lactate were infused $(n=4)$ and the ratio of the specific activities between ${ }^{3} \mathrm{H}$-labeled hepatic UDPglucose and portal vein plasma glucose furnished a measure of the direct pathway, while the ratio of specific activities between ${ }^{14} \mathrm{C}$-labeled hepatic UDPglucose and PEP measured the percent contribution of the indirect pathway. As shown in Table III, the sum of the contribution of the direct pathway, as calculated from the tritiated UDPglucose specific activity, and of the indirect pathway, calculated from the $\left[{ }^{14} \mathrm{C}\right]$ UDPglucose $/\left[{ }^{14} \mathrm{C}\right]$ PEP specific activities ratio, accounted for $\sim 93 \%$ of the overall liver glycogen synthesis in all studies. The contribution of glucose cycling and PEP gluconeogenesis to overall glucose output can also be calculated from the data in Table III. The hepatic glucose production was $2.5 \pm 0.3 \mu \mathrm{mol} / \mathrm{kg} \cdot \min$ in this subset of rats; the glucose cycling was not different from basal $(4.2 \pm 0.4$ vs. $3.9 \pm 0.3 \mu \mathrm{mol} /$ $\mathrm{kg} \cdot \mathrm{min}$ ) and the PEP gluconeogenesis was $2.1 \mu \mathrm{mol} / \mathrm{kg} \cdot \mathrm{min}$. The ratio of portal vein plasma lactate and hepatic PEP specific activities provides a measure of the dilution of the ${ }^{14} \mathrm{C}$ label in the oxalacetate pool, and was $1.76(n=4)$. In separate experiments, $\left[3-{ }^{3} \mathrm{H}, \mathrm{U}-{ }^{14} \mathrm{C}\right]$ glucose was infused, and a minimal estimation of the contribution of the indirect pathway to glycogen repletion was obtained by comparing the ratio of the relative specific activities of ${ }^{3} \mathrm{H}$ - and ${ }^{14} \mathrm{C}$-labeled UDPglucose and portal vein plasma glucose while the contribution of the direct pathway was calculated from the ratio of specific activities of ${ }^{3} \mathrm{H}$-labeled UDPglucose and plasma glucose. The minimal esti-

Table III. Substrate Specific Activities in $\left[3-{ }^{3} \mathrm{H}\right] \mathrm{Glucose}-\left[\mathrm{U}_{-}{ }^{14} \mathrm{C}\right]$ Lactate Studies

\begin{tabular}{|c|c|c|c|c|c|c|c|}
\hline Study & {$\left[{ }^{14} \mathrm{C}\right]$ LAC } & {$\left[{ }^{14} \mathrm{C}\right] \mathrm{PEP}$} & {$\left[{ }^{14} \mathrm{C}\right]$ UDPG } & {$\left[{ }^{3} \mathrm{H}\right]$ UDPG } & {$\left[{ }^{3} \mathrm{H}\right] \mathrm{GLU}$} & \%DIR & \%INDIR \\
\hline \multicolumn{8}{|c|}{$d p m / n m o l$} \\
\hline 1 & 12.9 & 7.42 & 5.83 & 6.41 & 11.2 & 57.2 & 39.1 \\
\hline 2 & 14.3 & 8.19 & 4.52 & 7.56 & 12.5 & 60.5 & 27.6 \\
\hline 3 & 16.1 & 8.93 & 5.27 & 7.06 & 10.1 & 69.8 & 29.5 \\
\hline 4 & 21.0 & 11.93 & 6.18 & 8.16 & 13.0 & 62.8 & 25.9 \\
\hline
\end{tabular}

Abbreviations: LAC, lactate; PEP, phosphoenolpyruvate; UDPG, uridinediphosphoglucose; GLU, glucose; \%DIR, percent direct pathway, calculated as the ratio of $\left[{ }^{3} \mathrm{H}\right]$ UDPG and $\left[{ }^{3} \mathrm{H}\right] \mathrm{GLU}$; \%INDIR, percent indirect pathway, calculated as the ratio of $\left[{ }^{14} \mathrm{C}\right] \mathrm{UDPG}$ and $2\left[{ }^{14} \mathrm{C}\right] \mathrm{PEP}$. These results were obtained at the end of hyperglycemic $(+11 \mathrm{mM})$ hyperinsulinemic clamp studies. 
Table IV. Substrate Specific Activities of $\left[6-{ }^{3} \mathrm{H}\right]-$ and $\left[3-{ }^{3} \mathrm{H}\right]$ Glucose Studies

\begin{tabular}{|c|c|c|c|}
\hline Study & {$\left[{ }^{3} \mathrm{H}\right]$ UDP glucose } & {$\left[{ }^{3} \mathrm{H}\right]$ glucose } & $\%$ Dir \\
\hline \multicolumn{4}{|c|}{$d p m / n m o l$} \\
\hline$\left[6-{ }^{3} \mathrm{H}\right]$ no. 1 & 8.58 & 16.1 & 53.3 \\
\hline$\left[6-{ }^{3} \mathrm{H}\right]$ no. 2 & 7.17 & 13.9 & 51.8 \\
\hline$\left[6-{ }^{3} \mathrm{H}\right]$ no. 3 & 8.20 & 14.8 & 55.4 \\
\hline$\left[6-{ }^{3} \mathrm{H}\right]$ no. 4 & 6.64 & 12.1 & 54.7 \\
\hline$\left[6-{ }^{3} \mathrm{H}\right]$ mean & 7.65 & 14.2 & 53.8 \\
\hline$\left[3-{ }^{3} \mathrm{H}\right]$ mean & $8.04 \pm 0.57$ & $15.7 \pm 2.8$ & $51.2 \pm 4.0$ \\
\hline
\end{tabular}

Abbreviation: \%DIR percent direct pathway, calculated as the ratio of $\left[{ }^{3} \mathrm{H}\right]$ UDPglucose and $\left[{ }^{3} \mathrm{H}\right]$ glucose. These results were obtained at the end of the hyperglycemic ( $+5.5 \mathrm{mM})$ hyperinsulinemic clamp studies.

mation of the indirect pathway obtained by the relative specific activities of ${ }^{3} \mathrm{H}$ - and ${ }^{14} \mathrm{C}$-labeled UDPglucose and portal vein plasma glucose was $59.3 \pm 5.2$ at $+5.5 \mathrm{mM}$ and $50.3 \pm 4.7$ at +11 $\mathrm{mM}$ plasma glucose in diabetic rats, and $39.4 \pm 2.9$ at $+5.5 \mathrm{mM}$ and $31.8 \pm 2.8$ at $+11 \mathrm{mM}$ plasma glucose in diabetic rats. In a separate group of control rats $(n=4)$, a maximal estimate of the direct pathway was also calculated with the infusion of [6$\left.{ }^{3} \mathrm{H}, \mathrm{U}-{ }^{14} \mathrm{C}\right]$ glucose (Table IV). The direct pathway of liver glycogen formation was significantly less stimulated in diabetic rats during both the hyperglycemic clamp studies $(+5.5 \mathrm{mM}-$ $32 \pm 5 \%$ vs. $51 \pm 4 \%$; $+11 \mathrm{mM}-38 \pm 3 \%$ vs. $63 \pm 4 \%$; diabetic vs. control rats, $P<0.01$ ). Fig. 5 depicts the contribution of the two pathways. $\left[3-{ }^{3} \mathrm{H}\right]$ UDPglucose specific activity in skeletal muscle was similar to peripheral plasma glucose specific activity in all the studies.
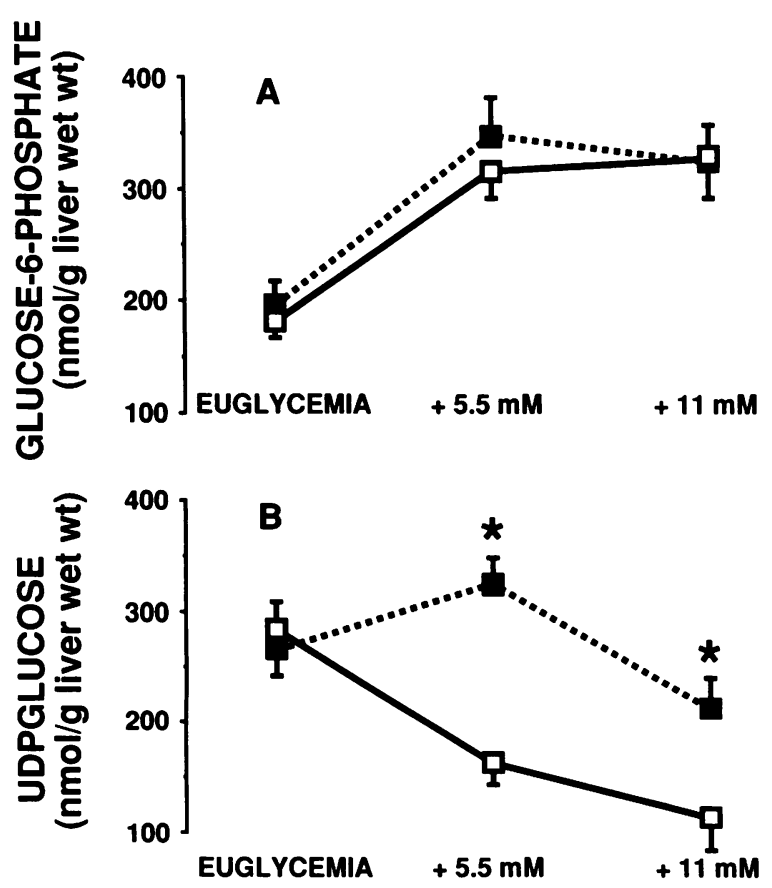

Figure 6. Effect of hyperglycemia on liver $(A)$ glucose-6-phosphate and $(B)$ UDPglucose concentrations in sham operated controls ( $\square$ ) and $90 \%$ pancreatectomized diabetic rats $(\square) .{ }^{*} P<0.01$ or less vs. controls at the same glucose level.
Concentrations of glucose-6-phosphate and UDPglucose in the liver. The glucose-6-phosphate concentrations (Fig. $6 \mathrm{~A}$ ) measured in liver homogenates collected at the end of the 120min euglycemic clamp studies, were not statistically different between the two groups ( $182 \pm 14$ and $196 \pm 20 \mu \mathrm{mol} / \mathrm{kg}$ tissue $\mathrm{wt}$, control and diabetic rats, respectively). At the end of both the hyperglycemic clamp studies the glucose-6-phosphate concentration was markedly and significantly increased, when compared with euglycemia, in both groups $(+5.5 \mathrm{mM}-$ $316 \pm 24$ and $347 \pm 34 \mu \mathrm{mol} / \mathrm{kg}$ tissue $\mathrm{wt} ;+11 \mathrm{mM}-326 \pm 31$ and $325 \pm 43 \mu \mathrm{mol} / \mathrm{kg}$ tissue $\mathrm{wt}$, control and diabetic rats, respectively). Liver UDPglucose concentrations (Fig. $6 \mathrm{~B}$ ) at the end of the 120 -min euglycemic clamp studies were similar between the two groups ( $285 \pm 24$ and $266 \pm 23 \mu \mathrm{mol} / \mathrm{kg}$ tissue wt, control and diabetic rats, respectively). However, when hyperglycemia was added over hyperinsulinemia, liver UDPglucose concentrations were markedly and progressively decreased in control rats $(+5.5 \mathrm{mM}-163 \pm 19 \mu \mathrm{mol} / \mathrm{kg}$ tissue $\mathrm{wt} ;+11 \mathrm{mM}$ $-113 \pm 29 \mu \mathrm{mol} / \mathrm{kg}$ tissue $\mathrm{wt}$ ), whereas in diabetic rats the hepatic UDPglucose concentration was unchanged during the $+5.5 \mathrm{mM}(326 \pm 22 \mu \mathrm{mol} / \mathrm{kg}$ tissue $\mathrm{wt})$ and was significantly decreased only during the $+11 \mathrm{mM}$ hyperglycemic clamp $(214 \pm 27 \mu \mathrm{mol} / \mathrm{kg}$ tissue wt; $P<0.05$ vs. euglycemia). At both hyperglycemic levels the hepatic UDPglucose concentration was twofold increased in diabetic compared to control rats $(P$ $<0.01$ ).

\section{Discussion}

In the present study we examined the effect of hyperglycemia, under identical conditions of hyperinsulinemia, on the major pathways of glucose metabolism in conscious control and diabetic rats.

As previously reported $(32,34,35)$, under euglycemic hyperinsulinemic conditions, diabetic rats demonstrate a major defect in skeletal muscle glycogen deposition, which completely accounts for the reduction in insulin-mediated wholebody glucose metabolism. When hyperglycemia was added over hyperinsulinemia, glycolysis was not further stimulated in either group, whereas muscle glycogen synthesis was markedly increased. This is consistent with the notion that, when the effect of hyperglycemia on glucose disposal is evaluated at high insulin concentrations, it determines a selective stimulation of glycogen synthesis, although the glycolytic pathway is not further increased over the level achieved with hyperinsulinemia alone (44). Diabetic rats displayed a significant decrease in insulin-mediated glucose uptake and in muscle glycogen synthesis at all the plasma glucose concentrations examined. However, the increment in skeletal muscle glycogen deposition induced by the increase in blood glucose concentration was similar in diabetic compared to control rats. This suggests that, in diabetic rats, under conditions of identical hyperinsulinemia, the stimulatory effect of hyperglycemia on the wholebody glucose disposal and on muscle glycogen synthesis is normal. The mass effect of hyperglycemia on overall and skeletal muscle glucose metabolism in the diabetic state has been examined by several investigators (44-53). Baron et al. (46) showed that the mass effect of hyperglycemia is preserved in insulin-resistant individuals. A similar conclusion was reached by the forearm balance technique by Capaldo et al. (47), who suggested that the mass effect of hyperglycemia on forearm glucose 
uptake in non-insulin-dependent diabetics is actually increased and compensates for insulin resistance, and by Revers et al. (48) and Henry et al. (49) at the whole-body level.

Over the last several years, numerous studies have suggested that, when a glucose load is administered to animals (7-20) or humans (21-24), a large portion of the liver glycogen is repleted by the indirect pathway. This issue has been addressed by several isotopic approaches, mainly based upon the detritiation of glucose in the indirect pathway, or the determination of the randomization of labeling carbons in UDPglucose (extracted from urine glycoconjugates) or glucosyl units in glycogen. In the present study, the contribution of the two pathways to liver glycogen repletion has been determined from the specific activities of hepatic UDPglucose and PEP, measured by HPLC (43). In this study, the contribution of the direct pathway to hepatic glycogen synthesis during the $+5.5 \mathrm{mM}$ and the $+11 \mathrm{mM}$ hyperglycemic clamp studies was severely decreased in diabetic compared to control rats (32\% vs. $51 \%$ and $38 \%$ vs. $63 \%$, respectively). Moreover, the net rate of liver glycogen synthesis was normal in diabetic rats and the absolute gluconeogenic flux to glycogen was markedly increased. These findings suggest that gluconeogenesis is the predominant mechanism by which diabetic rats replete their hepatic glycogen stores and may compensate for the decreased direct incorporation of glucose into glycogen. However, it should be noted that the contribution of the pathways to liver glycogen repletion may vary as a function of the plasma insulin concentration and of the route of glucose administration (2).

The specific activity of UDPglucose will reflect the specific activity of the newly formed glycogen and measures the contribution of the direct pathway to liver glycogen repletion at a specific time point. A major advantage of this method is its independence from the basal glycogen concentration. This is particularly important when evaluating hepatic glycogen synthesis in diabetic rats, in that they present high and variable glycogen concentrations even after $24-48$-h fast $(54,55)$. The choice of the tracers deserves some comments. The ideal tracer for the determination of the direct pathway of liver glycogen repletion would be the one whose label is retained only in the reactions glucose $\rightarrow$ glucose-6-phosphate $\rightarrow$ glucose-1-phosphate $\rightarrow$ UDPglucose $\rightarrow$ glycogen, and lost in water in every other pathway. The two tracers that better respond to these criteria are $\left[3-{ }^{3} \mathrm{H}\right]$ glucose and $\left[6-{ }^{3} \mathrm{H}\right]$ glucose $(11,12,14,15$, $17-24,56-72)$. The $\left[6-{ }^{3} \mathrm{H}\right]$ glucose carbon skeleton, however, retains a small percentage of the tritium label during its metabolism through glycolysis and in the tricarboxylic acid cycle. Thus, with the use of this tracer, the direct pathway of liver glycogen repletion may be overestimated. This may represent a problem particularly if a portion of the indirect pathway is intrahepatic and if the extent of this tracer error is predicted to be different in the experimental groups, i.e., diabetic state. [3${ }^{3} \mathrm{H}$ ]Glucose loses completely the label in its passage through glycolysis. However, a small percentage of $\left[3-{ }^{3} \mathrm{H}\right]$ glucose may also enter the pentose phosphate pathway, undergo detritiation at the ribulose-5-phosphate level, and reenter in the glucose-6-phosphate pool $(56,57)$. In fact, for each molecule of $\left[3-{ }^{3} \mathrm{H}\right]$ glucose that enters the pentose phosphate pathway (generating three $\mathrm{CO}_{2}$ and one glyceraldehyde-3-phosphate), about two other detritiated molecules of $\left[3-{ }^{3} \mathrm{H}\right]$ glucose-6-phosphate may reenter the glucose-6-phosphate pool and therefore dilute its specific activity. Thus, this tracer will determine an underes- timation of the direct pathway that is in direct proportion to the rate of the pentose phosphate cycle. Because the pentose phosphate cycle has been shown to be negligible in these experimental conditions (24) and, perhaps more importantly, it has been reported to be normal or decreased in diabetic animals $(57,72)$, this isotopic approach allows a reliable measure of the pathways of liver glycogen repletion in diabetic compared to control animals. Since the $\left[6-{ }^{3} \mathrm{H}\right]$ glucose provides a maximal and $\left[3-{ }^{3} \mathrm{H}\right]$ glucose provides a minimal estimate of the direct pathway of liver glycogen repletion, we compared these two tracers in a subgroup of control rats. During hyperglycemic (+5.5 mM) clamp studies the contribution of the direct pathway to liver glycogen synthesis was $54 \%$ with the $\left[6-{ }^{3} \mathrm{H}\right]$ glucose and $51 \%$ with the $\left[3-{ }^{3} \mathrm{H}\right]$ glucose (Table IV), suggesting that both tracer "errors" mentioned above are quantitatively negligible.

In order to validate our estimation of the indirect pathway, we performed additional hyperglycemic insulin clamp studies with $\left[3-{ }^{3} \mathrm{H}\right]$ glucose and $\left[\mathrm{U}-{ }^{14} \mathrm{C}\right]$ lactate infusions, and both liver UDPglucose and PEP specific activities were measured. With this methodology, the direct and indirect pathways of liver glycogen repletion could be independently measured. The sum of liver glycogen repletion through the PEP gluconeogenic pathway and the direct pathway accounted for $93 \%$ of the total glycogen synthesis, thus suggesting that, in these experimental conditions, the sum of the pentose phosphate pathway and the non-PEP gluconeogenesis represent $<7 \%$ of the glycogenic flux. The results obtained with the infusion of $\left[\mathrm{U}-{ }^{14} \mathrm{C}\right]$ glucose, by which a minimal estimate of the contribution of the indirect pathway can be calculated, seems to further validate the present findings.

Our results confirm that in the postabsorptive state the indirect pathway of hepatic glycogen repletion plays a predominant role (7-24). In control rats, the per cent contribution of the direct pathway to hepatic glycogen repletion was $13 \%$ and $51 \%$ during the euglycemic and the $+5.5 \mathrm{mM}$ hyperglycemic insulin clamp studies respectively, in close agreement with previous results obtained, under identical experimental conditions, by nuclear magnetic resonance spectroscopy (7). As suggested by Newgard et al. (12), Lang et al. (14), and Shulman et al. (7), the relative contribution of the direct pathways in control rats is mainly determined by the plasma glucose concentration and by the rates of hepatic glucose uptake.

Our experimental design allows the evaluation of the pathways of hepatic glycogen synthesis under identical hyperglycemic and hyperinsulinemic conditions in diabetic compared to control rats. Interestingly, diabetic rats, despite a reduced contribution of the direct pathway to liver glycogen synthesis, maintained similar rates of hepatic glycogen formation. Since glucose-6-phosphate can be formed in the liver either by the direct phosphorylation of glucose or via the gluconeogenic pathway, this may suggest that, in diabetic rats, the increased gluconeogenic flux in the glucose-6-phosphate pool may compensate for the decreased direct uptake of glucose. Recent studies suggest the presence of an homeostatic mechanism which regulates hepatic glucose production in normal dogs (73) and humans $(74,75)$. Our findings suggest that a similar process may be involved in the modulation of hepatic glycogen repletion as well, and that this proposed homeostatic mechanism may be acting at the level of the glucose-6-phosphate pool. In fact, in the present study, consistent with a previous report by 
Newgard et al. (76), in normal rats the presence of hyperglycemia determines a significant decrease in the intrahepatic UDPglucose concentration, and a gradual increase in the glucose-6-phosphate concentration. These results suggest that, under hyperinsulinemic conditions, hyperglycemia activates glycogen synthase, which in turn diverts glucose-6-phosphate into liver glycogen, the so called "pull" mechanism. Since the glucose-6-phosphate concentration does not mirror the fall in the UDPglucose concentration, a simultaneous inhibition of the glucose-6-phosphatase by insulin and/or glucose may also play a role in the observed changes in the intrahepatic substrate concentrations. By contrast, in diabetic rats, despite normal liver glycogen synthesis, the activity of the enzyme glycogen synthase is presumably reduced. In fact, the hepatic glucose-6-phosphate concentration was similar to controls, but the UDPglucose concentration was markedly increased, therefore maintaining high carbon flux through the glycogen synthetic pathway, by a "push" mechanism. It is tempting to speculate that the simultaneous increase in the gluconeogenic flux may be involved in this compensatory adjustment. The apparent decrease in glycogen synthase activity in diabetic rats may be related to the increased basal glycogen observed in this group. However, we could not demonstrate any correlation between the basal glycogen concentration and either the rate of glycogen deposition or the UDPG concentration.

Several factors may determine increased gluconeogenic flux to glycogen in diabetic rats. First, the gluconeogenic flux may be increased as a consequence of the reduced direct phosphorylation of glucose, in keeping with a homeostatic mechanism regulating the pathways of hepatic glycogen repletion. However, it is also possible that a primary activation of the gluconeogenic pathway would increase its flux to UDPglucose and glycogen and secondarily determine a reduction in the direct pathway. Gluconeogenesis may be stimulated by an increase in plasma glucagon or free fatty acid (FFA) concentration. However, although plasma glucagon and FFA concentrations were not measured in the present study, we have previously shown that this diabetic rat model presents normal basal and postinsulin plasma glucagon and FFA concentrations (36, 54). Additionally, the increment in plasma glucagon and FFA concentration would be expected to simultaneously stimulate gluconeogenesis and decrease the net glycogen synthesis (7781). A potential mechanism underlying the increased indirect pathway of glycogen repletion in diabetic rats is an increased supply of gluconeogenic precursors. Although the plasma concentration of alanine and glycerol were not measured in the present study, the plasma lactate concentration and the wholebody glycolytic flux were similar in diabetic and control rats. However, we cannot exclude that an increased hepatic delivery of gluconeogenic precursors may contribute to the preferential increase in the indirect pathway. Finally, the alteration in the pathways of hepatic glycogen formation may be the consequence of the chronic hypoinsulinemia, through the activation of the gluconeogenic enzymes $(29,82,83)$ and the decrease in glucokinase activity (84).

The present study provides a new quantitative approach to the measurement of the pathways of liver glycogen repletion in conscious rats. This methodology is particularly useful in conditions associated with high basal hepatic glycogen concentration, such as the fed or the diabetic states. Our data suggest that the glucose concentration is the major determinant of the rela- tive contribution of the direct pathway to liver glycogen repletion in both control and diabetic rats. However, the presence of prolonged moderate hyperglycemia and hypoinsulinemia determines a marked reduction in the ability of glucose to stimulate the direct pathway in this diabetic rat model. Nevertheless, the rates of hepatic glycogen synthesis were similar in diabetic and control rats, when measured at equal hyperglycemic and hyperinsulinemic levels. The increased gluconeogenic flux and a "push" mechanism for hepatic glycogen synthesis in diabetic rats may reconcile this apparent paradox. In conclusion, these results suggest that in the diabetic state a chronic activation of the carbon flux through the gluconeogenic pathway can promote glucose production or glycogen synthesis dependent on the hormonal and metabolic signal presented to the liver.

\section{Acknowledgments}

The authors would like to thank Eveline Klein-Robbenhaar for her excellent technical assistance and Stella Merla for her expert secretarial assistance.

This work was supported by grants to Dr. Rossetti from the American Heart Association (No. 900671) and the Juvenile Diabetes Foundation (No. 188016). Dr. Giaccari is the recipient of a scholarship (Dottorato di Ricerca) from the University of Rome "La Sapienza," Italy.

\section{References}

1. Shulman, G. I., and L. Rossetti. 1989. Influence of the route of glucose administration on hepatic glycogen repletion. Am. J. Physiol. 257:E681-E685.

2. Adkins, B. A., S. R. Myers, G. K. Hendrick, R. W. Stevenson, P. E. Williams, and A. D. Cherrington. 1987. Importance of the route of intravenous glucose delivery to hepatic glucose balance in the conscious dog. J. Clin. Invest. 79:557-565.

3. Barrett, E. J., E. Ferrannini, R. Gusberg, S. Bevilacqua, and R. A. DeFronzo. 1985. Hepatic and extrahepatic splanchnic glucose metabolism in the postabsorptive and glucose fed dog. Metab. Clin. Exp. 34:410-420.

4. Bergman, N. R., J. R. Beir, and P. M. Hourigan. 1982. Intraportal glucose infusion matched to oral glucose absorption. Diabetes. 31:27-35.

5. DeFronzo, R. A., E. Ferrannini, R. Hendler, J. Wahren, and P. Felig. 1978. Influence of hyperinsulinemia, hyperglycemia, and the route of glucose administration on splanchnic glucose exchange. Proc. Natl. Acad. Sci. USA. 74:51735177.

6. Ishida, T., Z. Chap, J. Chou, R. Lewis, C. Hartley, M. Entman, and J. B. Field. 1983. Differential effects of oral, peripheral intravenous, and intraportal glucose on hepatic glucose uptake and insulin and glucagon extraction in conscious dog. J. Clin. Invest. 72:590-600.

7. Shulman, G. I., L. Rossetti, D. L. Rothman, J. B. Blair, and D. Smith. 1987. Quantitative analysis of glycogen repletion by nuclear magnetic resonance spectroscopy in the conscious rat. J. Clin. Invest. 80:387-393.

8. Shulman, G. I., D. L. Rothman, D. Smith, C. M. Johnson, J. B. Blair, R. G. Shulman, and R. A. DeFronzo. 1985. Mechanism of liver glycogen repletion in vivo by nuclear magnetic resonance spectroscopy. J. Clin. Invest. 76:1229-1236.

9. Rossetti, L., D. L. Rothman, R. A. DeFronzo, and G. I. Shulman. 1989. Effect of dietary protein on in vivo insulin action and liver glycogen repletion. Am. J. Physiol. 257:E212-E219.

10. Shulman, G. I., D. L. Rothman, Y. Chung, L. Rossetti, W. A. Petit, Jr., E. J. Barrett, and R. G. Shulman. 1988. 13C NMR studies of glycogen turnover in the perfused rat liver. J. Biol. Chem. 263:5027-5029.

11. Newgard, C. B., S. V. Moore, D. W. Foster, and J. D. McGarry. 1984. Efficient hepatic glycogen synthesis in refeeding rats requires continued carbon flow through the gluconeogenic pathway. J. Biol. Chem. 259:6958-6963.

12. McGarry, J. D. 1990. Hepatic glucose-6-phosphate cycling has no bearing on recently used isotopic procedures to investigate the pathways of glycogen synthesis. Metab. Clin. Exp. 37:332.

12. Newgard, C. B., L. J. Hirsch, D. W. Foster, and J. D. McGarry. 1983. Studies on the mechanism by which exogenous glucose is converted into liver glycogen in the rat: a direct or an indirect pathway? J. Biol. Chem. 258:80468052 .

13. Katz, J., and J. D. McGarry. 1984. The glucose paradox. Is glucose a substrate for liver metabolism? J. Clin. Invest. 74:1901-1909. 
14. Lang, C. H., G. J. Bagby, H. L. Blakesley, J. L. Johnson, and J. J. Spitzer. 1986. Plasma glucose concentration determines direct versus indirect liver glycogen synthesis. Am. J. Physiol. 251:E584-E590.

15. Spence, J. T., and A. P. Koudelka. 1985. Pathway of glycogen synthesis from glucose in hepatocytes maintained in primary culture. J. Biol. Chem. 260:1521-1526.

16. Scofield, R. F., K. Kosugi, W. C. Schumann, K. Kumaran, and B. R. Landau. 1985. Quantitative estimation of the pathways followed in the conversion to glycogen of glucose administered to fasted rats. J. Biol. Chem. 260:87778782 .

17. McGarry, J. D., M. Kuwajima, C. B. Newgard, D. W. Foster, and J. Katz. 1987. From dietary glucose to liver glycogen: the full circle round. Annu. Rev. Nutr. 7:51-73.

18. Hellerstein, M. K., D. J. Greenblatt, and H. N. Munro. 1986. Glycoconjugates as noninvasive probes of intrahepatic metabolism: pathways of glucose entry into compartmentalized hepatic UDP-glucose pools during glycogen accumulation. Proc. Natl. Acad. Sci. USA. 83:7044-7048.

19. Kurland, I. J., and S. J. Pilkis. 1989. Indirect versus direct routes of hepatic glycogen synthesis. FASEB (Fed. Am. Soc. Exp. Biol.) J. 3:2277-2281.

20. Huang, M.-T., and R. Veech. 1988. Role of the direct and indirect pathways for glycogen synthesis in rat liver in the postprandial state. J. Clin. Invest. 81:872-878.

21. Radziuk, J. 1989. Hepatic glycogen in humans. I. Direct formation after oral and intravenous glucose or after 24-h fast. Am. J. Physiol. 257:E145-E157.

22. Radziuk, J. 1989. Hepatic glycogen in humans. II. Gluconeogenetic formation after oral and intravenous glucose. Am. J. Physiol. 257:E158-E169.

23. Magnusson, I., V. Chandramouli, W. C. Schumann, K. Kumaran, J. Wahren, and B. R. Landau. 1987. Quantitation of the pathways of hepatic glycogen formation on ingesting a glucose load. J. Clin. Invest. 80:1748-1754.

24. Shulman, G. I., G. Cline, W. C. Schumann, V. Chandramouli, K. Kumaran, and B. R. Landau. 1990. Quantitative comparison of pathways of hepatic glycogen repletion in fed and fasted humans. Am. J. Physiol. 259:E335-E341.

25. Bogardus, C., S. Lillioja, B. V. Howard, G. Reaven, and D. Mott. 1984. Relationship between insulin secretion, insulin action and fasting plasma glucose concentration in nondiabetic and noninsulin-dependent diabetic subjects. $J$. Clin. Invest. 74:1238-1246.

26. Consoli, A., F. Kennedy, J. Miles, and J. Gerich. 1987. Determination of krebs cycle metabolic carbon exchange in vivo and its use to estimate the individual contributions of gluconeogenesis and glycogenolysis to overall glucose output in man. J. Clin. Invest. 80:1303-1310.

27. Consoli, A., N. Nurjhan, F. Capani, and J. Gerich. 1989. Predominant role of gluconeogenesis in increased hepatic glucose production in NIDDM. Diabetes. 38:550-557.

28. Yki-Jarvinen, H., E. Helve, T. Sane, N. Nurjhan, and M. R. Taskinen. 1989. Insulin inhibition of overnight glucose production and gluconeogenesis from lactate in NIDDM. Am. J. Physiol. 256:E732-E739.

29. Nimmo, H. G., and P. T. W. Cohen. 1987. Applications of recombinant DNA technology to studies of metabolic regulation. Biochem. J. 247:1-13.

30. Foglia, V. G. 1944. Caracteristicas de la diabetes en la rata. Rev. Soc. Argent. Biol. 20:21-37.

31. Bonner-Weir, S., D. F. Trent, and G. C. Weir. 1983. Partial pancreatectomy in the rat and subsequent defect in glucose-induced insulin release. J. Clin. Invest. 71:1544-1553.

32. Rossetti, L., and A. Giaccari. 1990. Relative contribution of glycogen synthesis and glycolysis to insulin-mediated glucose uptake: a dose-response euglycemic clamp study in normal and diabetic rats. J. Clin. Invest. 85:1785-1792.

33. Rossetti, L., D. Smith, G. I. Shulman, D. Papachristou, and R. A. DeFronzo. 1987. Correction of hyperglycemia with phlorizin normalizes tissue sensitivity to insulin in diabetic rats. J. Clin. Invest. 79:1510-1515.

34. Rossetti, L. 1989. Normalization of insulin sensitivity with lithium in diabetic rats. Diabetes. 38:648-652.

35. Rossetti, L., and M. R. Laughlin. 1989. Correction of chronic hyperglycemia with vanadate, but not phlorizin, normalizes in vivo glycogen repletion and in vitro glycogen synthase activity in diabetic skeletal muscle. J. Clin. Invest. 84:892-899.

36. Smith, D., L. Rossetti, E. Ferrannini, C. M. Johnson, C. Cobelli, G. Toffolo, L. D. Katz, and R. A. DeFronzo. 1987. In vivo glucose metabolism in the awake rat: tracer and insulin clamp studies. Metab. Clin. Exp. 36:1176-1186.

37. Young, A. A., C. Bogardus, D. Wolfe-Lopez, and D. M. Mott. 1988. Muscle glycogen synthesis disposition of infused glucose in humans with reduced rates of insulin-mediated carbohydrate storage. Diabetes. 37:303-308.

38. Karlander, S., A. Roovete, M. Vranic, and S. Efendic. 1986. Glucose and fructose-6-phosphate cycle in humans. Am. J. Physiol. 251:E530-E536.

39. Hostler, K. Y., and B. R. Landau. 1967. Estimation of the pentose cycle contribution to glucose metabolism in tissue in vivo. Biochemistry. 6:2961-2964.

40. Spence, J. T., and A. P. Koudelka. 1985. Pathway of glycogen synthesis from glucose in hepatocytes maintained in primary culture. J. Biol. Chem. 260:1521-1526.
41. Noll, S. 1985. L-Lactate. In Methods of Enzymatic Analysis. Volume VI. N. U. Bergmeyer, editor. VCH Verlagsgesellschaft mbH, Weinheim, FRG. 582588.

42. Michal, G. 1985. In Methods of Enzymatic Analysis. Vol. VI. N. U. Bergmeyer, editor. VCH Verlagsgesellschaft mbH, Weinheim, FRG. 191-198.

43. Giaccari, A., and L. Rossetti. 1989. Isocratic high-performance liquid chromatographic determination of the concentration and specific radioactivity of phosphoenolpyruvate and uridine diphosphate glucose in tissue extracts. J. Chromatogr. 497:69-78.

44. Ferrannini, E., L. Locatelli, and J. P. Felber. 1989. Differential effects of insulin and hyperglycemia on intracellular glucose dispositions in humans. $\mathrm{Me}$ tab. Clin. Exp. 38:459-465.

45. Yki-Jarvinen, H., D. Mott, A. A. Young, K. Stone, and C. Bogardus 1987. Regulation of glycogen synthase and phosphorylase activities by glucose and insulin in human skeletal muscle. J. Clin. Invest. 80:95-100.

46. Baron, A. D., O. G. Kolterman, J. Bell, L. J. Mandarino, and J. M. Olefsky. 1985. Rates of noninsulin-mediated glucose uptake are elevated in type II diabetic subjects. J. Clin. Invest. 76:1782-1788.

47. Capaldo, B., D. Santoro, G. Riccardi, N. Perrotti, and L. Sacca. 1986. Direct evidence for a stimulatory effect of hyperglycemia per se on peripheral glucose disposal in type II diabetes. J. Clin. Invest. 77:1285-1290.

48. Revers, R. R., R. Fink, J. Griffin, J. M. Olefsky, and O. G. Kolterman. 1984. Influence of hyperglycemia on insulin's in vivo effects in type II diabetes. $J$. Clin. Invest. 73:664-672.

49. Henry, R. R., B. Gumbiner, T. Flynn, and A. W. Thorburn. 1990. Metabolic effects of hyperglycemia and hyperinsulinemia on fate of intracellular glucose in NIDDM. Diabetes. 39:149-156.

50. DeFronzo, R. A., R. Gunnarsson, O. Bjorkman, and J. Wahren. 1985. Effect of insulin on peripheral and splanchnic glucose metabolism in noninsulindependent (Type II) diabetes mellitus. J. Clin. Invest. 76:149-155.

51. Yki-Jarvinen, H., A. A. Young, C. Lamkin, and J. E. Foley. 1987. Kinetics of glucose disposal in whole body and across forearm in man. J. Clin. Invest. 79:1713-1719.

52. Golay, A., Y. Schutz, H. U. Meyer, T. Thiebaud, B. Curchod, E. Maeder, J. P. Felber, and E. Jequier. 1982. Glucose-induced thermogenesis in nondiabetic and diabetic obese subjects. Diabetes. 31:1023-1028.

53. Bell, P. M., R. G. Firth, and R. A. Rizza. 1986. Effects of hyperglycemia on glucose production and utilization in humans: measurements with $\left[2^{3} \mathrm{H}\right]$-, $\left[3^{3} \mathrm{H}\right]$-, and $\left[6{ }^{14} \mathrm{C}\right]$-glucose. Diabetes. 35:642-648.

54. Rossetti, L., A. Giaccari, E. Klein-Robbenhaar, and L. R. Vogel. 1990. Insulinomimetic properties of trace elements and characterization of their in vivo mode of action. Diabetes. 39:1243-1250.

55. Rossetti, L., R. A. DeFronzo, R. Gherzi, P. Stein, G. Andraghetti, G. Falzetti, G. I. Shulman, E. Klein-Robbenhaar, and R. Cordera. 1990. Effect of metformin treatment on insulin action in diabetic rats: in vivo and in vitro correlations. Metab. Clin. Exp. 39:425-435.

56. Scofield, R. F., K. Kosugi, V. Chandramouli, K. Kumaran, W. C. Schumann, and B. R. Landau. 1985. The nature of the pentose pathway in the liver. $J$. Biol. Chem. 260:15439-15444.

57. Wajngot, A., V. Chandramouli, W. C. Schumann, K. Kumaran, S. Efendic, and B. R. Landau. 1989. Testing of the assumptions made in estimating the extent of futile cycling. Am. J. Physiol. 256:E668-E675.

58. Lang, C. H., G. J. Bagby, D. M. Hargrove, P. M. Hyde, and J. J. Spitzer. 1987. Alterations in glucose kinetics induced by pentobarbital anesthesia. Am. J. Physiol. 253:E657-E663.

59. El-Refai, M., and R. N. Bergman. 1976. Simulation study of hepatic glycogen synthesis by glucose and insulin. Am. J. Physiol. 231:1608-1619.

60. Hers, R. G. 1976. The control of glycogen metabolism in the liver. Annu. Rev. Biochem. 45:167-189.

61. Youn, J. H., and R. N. Bergman. 1990. Enhancement of hepatic glycogen by gluconeogenic precursor: substrate flux or metabolic control? Am. J. Physiol. 258:E899-E906.

62. Shiota, M., S. Golden, and J. Katz. 1984. Lactate metabolism in the perfused rat hindlimb. Biochem. J. 222:281-292.

63. Hellerstein, M. K., D. J. Greenblatt, and H. N. Munro. 1987. Glycoconjugates as noninvasive probes of intrahepatic metabolism. I. Kinetics of label incorporation with evidence of a common precursor UDP-glucose pool for secreted glycoconjugates. Metab. Clin. Exp. 36:988-994.

64. Hellerstein, M. K., and H. N. Munro. 1987. Glycoconjugates as noninvasive probes of intrahepatic metabolism. III. Application to galactose assimilation by the intact rat. Metab. Clin. Exp. 37:312-317.

65. Rognstad, R. 1989. Errors in estimations of hepatic glycogen synthesis and glucose output. Metab. Clin. Exp. 38:619-624.

66. Youn, J. H., M. Ader, and R. N. Bergman. 1989. Glucose phosphorylation is not rate limiting for accumulation of glycogen from glucose in perfused livers from fasted rats. J. Biol. Chem. 264:168-172.

67. Magnusson, I., V. Chandramouli, W. C. Schumann, K. Kumaran, J. 
Wahren, and B. R. Landau. 1988. Pentose pathway in human liver. Biochemistry. 85:4682-4685.

68. Landau, B. R. 1990. Futile cycling and purity revisited. Metab. Clin. Exp. 37:327-329.

69. Landau, B. R. 1990. Glucose-6-phosphatase cannot differentiate between glucose-6-P formed in the direct and indirect pathways. Metab. Clin. Exp. $37: 329-331$.

70. Katz, J. 1990. On the measurement of pathways of glycogen synthesis. Metab. Clin. Exp. 37:331.

71. Kuwajima, M., C. B. Newgard, D. W. Foster, and J. D. McGarry. 1986 The glucose-phosphorylating capacity of liver as measured by three independent assays. Implications for the mechanism of hepatic glycogen synthesis. J. Biol. Chem. 261:8849-8853.

72. Seifer, S., and S. England. 1983. In Diabetes Mellitus. 3rd edition. M. Ellenberg and H. Rifkin, editors. Medical Examination, New Hyde Park, NY. $1-46$.

73. Diamond, M. P., R. C. Rollins, K. E. Steiner, P. E. Williams, W. W. Lacy, and A. D. Cherrington. 1988. Effect of alanine concentration independent of changes in insulin and glucagon on alanine and glucose homeostasis in the conscious dog. Metab. Clin. Exp. 37:28-33.

74. Jahoor, F., E. J. Peters, and R. B. Wolfe. 1990. The relationship between gluconeogenic substrate and glucose production in humans. Am. J. Physiol. 258:E288-E296.

75. Wolfe, R. B., F. Jahoor, and J. H. F. Shaw. 1986. Effect of alanine infusion on glucose and urea production in man. J. Parenter. Enteral Nutr. 11:109-111.

76. Newgard, C. B., D. W. Foster, and J. D. McGarry. 1984. Evidence for suppression of hepatic glucose-6-phosphatase with carbohydrate feeding. Diabetes. 33:192-195.

77. Stevenson, R. W., K. E. Steiner, M. A. Davis, G. K. Hendrick, P. E. Williams, W. W. Lacy, L. Brown, P. Donahue, D. B. Lacy, and A. D. Cherrington. 1987. Similar dose responsiveness of hepatic glycogenolysis and gluconeogenesis to glucagon in vivo. Diabetes. 36:382-389.

78. Cherrington, A. D., P. E. Williams, G. I. Shulman, and W. W. Lacy. 1981. Differential time course of glucagon's effect on glycogenolysis and gluconeogenesis in the conscious dog. Diabetes. 30:180-187.

79. Ruderman, N. B., C. J. Toeus, and E. Shafir. 1969. Role of free fatty acids in glucose homeostasis. Arch. Intern. Med. 123:299-312.

80. Blumenthal, S. A. 1983. Stimulation of gluconeogenesis by palmitic acid in rat hepatocytes: evidence that this effect can be dissociated from provision of reducing equivalents. Metab. Clin. Exp. 32:971-976.

81. Williamson, J. R., R. A. Kreisberg, and P. W. Felts. 1966. Mechanism for the stimulation of gluconeogenesis by fatty acids in perfused rat liver. Proc. Natl. Acad. Sci. USA. 56:247-254.

82. Granner, D. K., and T. L. Andreone. 1985. Insulin modulation of gene expression. Diabetes/Metab. Rev. 1:139-170.

83. Sasaki, K., T. P. Cripe, S. R. Koch, T. L. Andreone, D. D. Peterson, E. G. Beale, and D. K. Granner. 1984. Multihormonal regulation of phosphoenolpyruvate carboxykinase gene transcription. The dominant role of insulin. J. Biol. Chem. 259:15242-15251.

84. Alvares, F. L., and R. C. Nordlie. 1977. Quantitative correlation of glucose uptake and phosphorylation with the activities of glucose-phosphorylating enzymes in perfused rat livers of fasted and fed rats. J. Biol. Chem. 252:8404-8414. 